\title{
Global Mutual Fund Industry Comparisons: Canada, The United Kingdom And The United States
}

\author{
Brian D. Fitzpatrick, Rockhurst University, USA \\ Daniel C. Hepp \\ Erinn J. Lott
}

\begin{abstract}
The concept of mutual funds is older than many believe, originating in Holland over 230 years ago. Through the years, mutual funds have evolved by allowing investors to invest their capital in various venues. The structure of mutual funds in Canada, the United Kingdom, and the United States possess similar configurations. The majority of funds in all three nations are invested in the equity market. Although the structure may be the same, the size in terms of assets varies by these three countries. This is not the only difference though; the expense ratio is greatly differentiated, dramatically affecting the amount of return that the investor will anticipate over time. Assuming identical returns, the authors illustrate that over a hypothetical ten-year time period, your funds would grow the most in the United States, followed by the United Kingdom and finally Canada. This analysis assumes comparable contemporary expense ratios of $1.4 \%$ for the United States, $1.63 \%$ for the United Kingdom, and $2.1 \%$ for Canada. In addition, we make the assumption that these comparison countries are having investors procure funds in no-load mutual funds.
\end{abstract}

Keywords: Canada, commercial paper, expense ratios, foreign bonds, global funds, growth funds, income funds, no-load mutual funds, United Kingdom, United States

\section{INTRODUCTION}

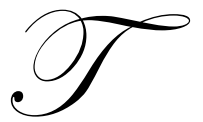

he mutual fund industry was created over 230 years ago in Holland, making it seem older than many people often perceive. In 1774, Adriaan van Ketwich created an investment trust entitled Eendragt Maakit Magt, which, when translated into English, means 'Unity Creates Strength'. The trust received aid from investors who pooled their capital together to invest in bonds. The main goal of this investment trust was to diversify risk by investing in bonds in foreign economies; i.e., Austria, Denmark, the German states, Spain, Sweden, Russia, and many other plantations in Central and South America. The decision to invest in foreign bonds instead of domestic bonds was due to the Amsterdam Stock Exchange not having Dutch government and municipal bonds. After only 25 years, the trust was dissolved due to a gradual but steady decline in outstanding shares.

In the United States, the idea of pooling money together for investing purposes was utilized in 1893 for the faculty and staff at Harvard University. In March 1924, the first mutual fund was born; i.e., Massachusetts Investors Trust. The main goal of this trust seeks to make profit by investing not in bonds as was the case in Unity Creates Strength, but in common stocks. ${ }^{2}$ Although it has been over 230 years since the formation of the first investment trust, the approach is still the same today. There are many similarities pertaining to mutual funds between the United Kingdom, Canada and the United States, but one stands apart from the rest; i.e., the structure of the mutual fund industries. However, there are numerous differences in these countries, including the amount of assets held by each

\footnotetext{
${ }^{1}$ Viking. "The Origins of Mutual Funds." Yale. 11/25/2005. http://viking.som.yale.edu/geert/origins.html

${ }^{2}$ About. "The History of Mutual Funds." About.com. 12/1/2005 http://mutualfunds.about.com/cs/history/a/fund_history.htm
} 
country and the various fees associated with managing mutual funds. The purpose of this paper is to compare and contrast mutual fund investing in Canada, The United Kingdom and The United States.

\section{CLARIFICATION}

When Ketwich created United Creates Strength, the investment trust achieved gains by investing in various foreign bond markets. Today, however, mutual funds achieve profits not solely on the bond market, but through numerous other avenues. The first means in which mutual funds achieve profit is investment in money market accounts. The goal of money market funds is to achieve performance by investing in relatively safe securities. Often, money market accounts are highly liquid because they invest in certificates of deposits, U. S. Treasury bills, commercial paper, and repurchase agreements. Bond funds make profits by not only investing in domestic bonds, but also in certificates of debt that are issued by foreign countries. The bond funds and money market funds are considered the least risky among the various fund types. ${ }^{3}$

Another common approach for creating profits in mutual funds is investing in asset allocation funds, growth funds, and income funds. Here the mutual funds invest in a combination of stocks and bond securities. Stock funds invest in stocks of companies who have the potential for growth. These would include companies who are in the rapid and mature growth stage. These approaches are considered to have a higher risk than the preceding approaches. ${ }^{4}$

The stock funds are followed by global/international funds which invest in a worldwide mixture of stocks and bonds. The next type of mutual fund is the sector type, which invests in a single sector of an economy. This might include investing in the automotive or the telecommunication industry. Another type of mutual fund is an index fund, which basically mirrors specific indexes; this may include index funds that mimic the performance of the Standard and Poor 500.5

Figure 1 shows these various approaches in mutual fund investing. The left side shows the most conservative, lowest risk mutual fund option - money market accounts, where the goal is to preserve capital. The second least risky type of mutual fund is the bond income fund, followed by the growth and income/asset allocation approach, followed by high risk global international equity funds, and concluding with sector and specialty funds. Growth or international equity is considered riskier than money market accounts because it invests in more volatile securities, including foreign stocks and bonds, instead of certificates of deposit and treasury bills. It should be noted, however, that although the sector type and specialty funds have a considerable amount of risk, they also have the ability to achieve very high returns on investment.

Figure 1: Different Types of Mutual Funds

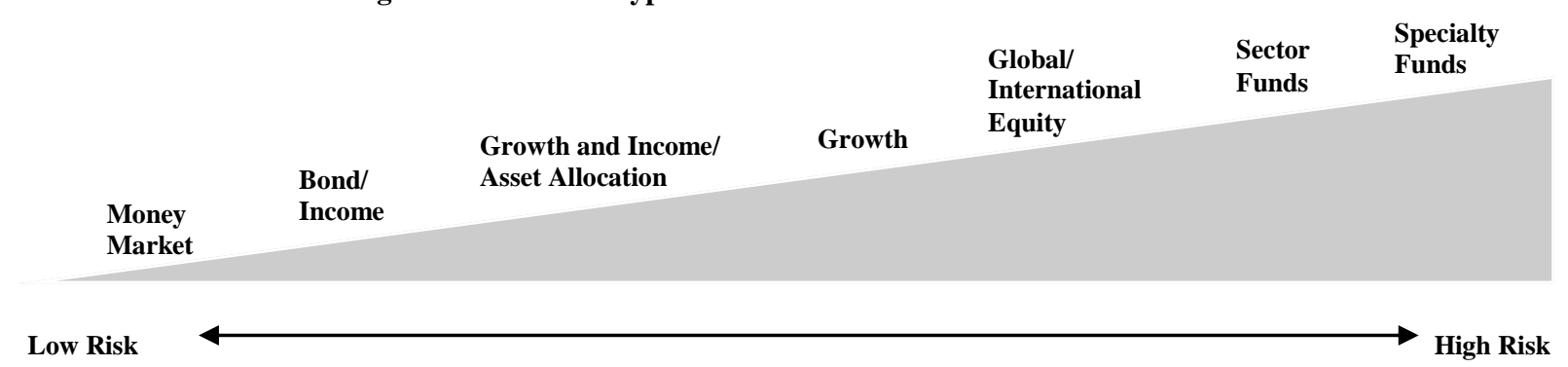

Objective: Capital Preservation

Objective: High Growth Potential

\footnotetext{
${ }^{3}$ Wells Fargo. "Types of Mutual Funds." Wells Fargo. 11/30/2005. http://mutualfunds.about.com/cs/history/a/fund_history.htm

${ }^{4}$ Wells Fargo. "Types of Mutual Funds."

${ }^{5}$ Wells Fargo. "Types of Mutual Funds."
} 
Spurred on by a movement in 1822, mutual funds first hit Great Britain and other European countries soon thereafter. It was not until the 1920s that mutual funds began being utilized in the United States and other North American countries, such as Canada. ${ }^{6}$ These three countries provide a focal point for the study of the similarities and differences of the mutual fund industry. In order to properly compare and contrast mutual funds within these three countries, it is important to note the main advantages and disadvantages of mutual funds as they provide key comparisons that are important to investors considering investing in foreign mutual funds; namely, funds in Canada or the United Kingdom.

Mutual funds have long been an investment company offering distinct advantages to investors, including diversification, convenience, liquidity and professional management. ${ }^{7}$ These advantages help to link and set apart mutual funds in the U.S., Canada and the United Kingdom as will be discussed in detail later. First, a look at the advantages of funds:

1. Diversification comes naturally for a mutual fund as a fund generally invests in a wide range of stocks and other investment vehicles. Ownership in a mutual fund means ownership in each particular security within the fund, which creates the ability to minimize risk as losses are offset by the other holdings of the fund. Much like each fund holding different investments, so too do the funds of the U.S., Canada and the United Kingdom.

2. Investing in mutual funds offers a convenience that is not usually available to investors who choose individual stocks, bonds or other instruments. Choosing mutual funds allows investors, who are not particularly interested in closely watching their portfolios, the ease of selecting an investment that is managed for them. Investors are able to choose funds aligning closely with their investment goals and risk level while not struggling with analysis and the continuous work of reassessing their portfolio. The ease of investing in funds is also dependent on their availability as we will see in looking at funds offered in the U.S., Canada and the United Kingdom.

3. Shares of a mutual fund can be converted into cash simply by requesting it be done. Many fund companies also allow investors to move from one fund to another as long as they remain within the same fund family. This allows investors the ease of changing their portfolio as their risk levels or financial goals change. Regulations and market climate might have a large impact on whether or not liquidity is a problem.

4. The assets of a fund are managed by professional managers dedicated solely to one particular fund much of the time. These managers are responsible for providing the knowledge and expertise that might otherwise be missing if an investor were on their own. Rather than an investor having to constantly recreate their portfolio, managers serve to alter the portfolio in order to align it with the investment objective of the fund.

Despite these advantages offered by mutual funds, there arise various disadvantages, including costs ${ }^{8}$ (e.g., brokerage fees, 12b-1 fees, management fees, professional management, dilution and taxes incurred throughout the ownership of a fund. The disadvantages of mutual funds clearly differentiate funds within the U.S., Canada and the United Kingdom. The disadvantages are as follows:

1. Funds are in business to make a profit, just as any other business venture and as such, the investors in that fund must cover the expenses of maintaining and increasing the fund value. These costs are often hidden by fund companies under layers of complex wordings and legal language. The operating expenses for funds are similar for the countries, yet the expense ratios differ.

2. Managers of funds theoretically carry the expertise necessary to make investors money. However, they don't always succeed in making money, at least for the investor. Some might argue that professional managers have no more skill than individual investors. Whether they do or not, the managers win as they collect a percentage of fees or gains in profitable years. Of increasing interest is the ethical nature of these managers and whether or not they are making ethical decisions in regard to investors. Regulations differ in varying degrees among the three countries.

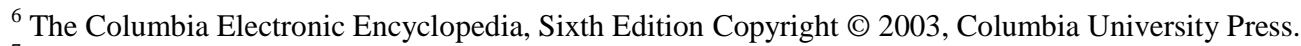

${ }^{7}$ http://finance.yahoo.com/funds/basics/article/100623/Advantages of Mutual Funds

8 http://chinese-school.netfirms.com/abacus-mutual-funds-advantages.html
} 
3. Despite diversification being an advantage of mutual fund investing, many investors believe that it is possible for a fund to be over-diversified. In this instance, large returns from a small number of investments will not necessarily impact the total return of the fund. Dilution can also occur when a fund's success attracts a large number of new investors. Managers might find it difficult to direct the inflow of cash toward profitable investments for the fund. ${ }^{9}$

4. As with any other investment that is sold at a profit, capital gains of mutual funds are subject to taxation. The required distributions of dividends to investors within a fund are also considered income and are therefore taxable. This becomes significant for investors when considering at what point to purchase a fund. Gains and distributions are taxed differently, especially if the funds are invested within a retirement account.

\section{DIVERSIFICATION}

Funds within the U.S. seem to focus more heavily on investing in Capital Appreciation Equity funds, Taxable Money Market funds and Total Return Equity funds as is shown in Figure 2. These three fund classes contain approximately $65 \%$ of the total net assets of U.S. mutual funds at the year end 2004. This is, in part, due to the growing use of mutual funds by U.S. investors to help meet their long-term investment goals; more specifically, retirement. ${ }^{10}$ Similarly, Canadian investors also choose to invest heavily in Equity but have larger stakes in Balanced and Other funds, as exhibited by Figure 3. Interestingly, the U.S. has no classification of Other funds. This is supported by the evidence that between 1994-2004 Balanced funds were the No. 1 choices for Canadians as popularity of the funds rose. ${ }^{11}$ Investment statistics are significantly higher in Great Britain for Equity Funds while Bond funds follow as the second most sold asset class, as evidenced by Figure 4.

Figure 2: U.S. Mutual Fund Industry Total Net Assets by Investment Classification (billions of dollars, end of year)

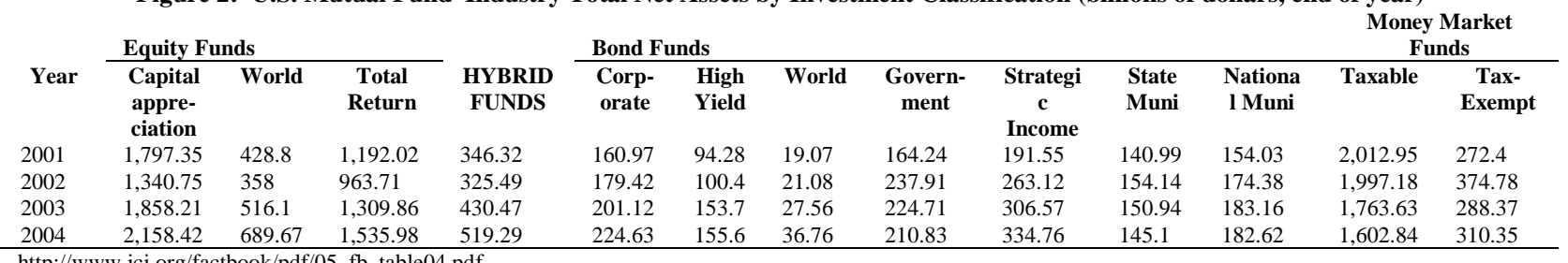

Figure 3: Canadian Assets December 31, 2004

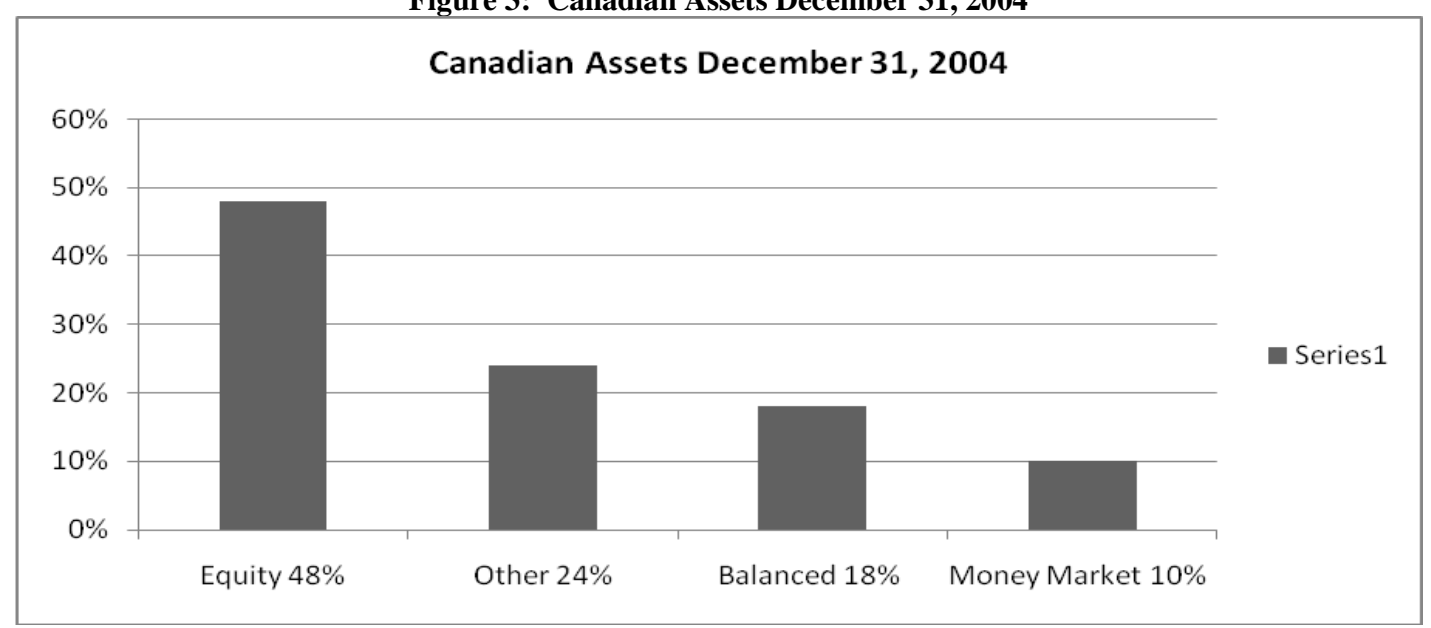

https://statistics.ificmembers.ca/English/reports/OverviewReport.asp?report=Review_2004

\footnotetext{
${ }^{9} \mathrm{http}: / /$ chinese-school.netfirms.com/abacus-mutual-funds-advantages.html

${ }^{10} \mathrm{http} / / / \mathrm{www}$.ici.org/factbook/05 fb sec2.html\#individual investors

11 https://statistics.ificmembers.ca/English/reports/Canada-US_Review.pdf
} 
Figure 4: Summary of Funds Under Management by Asset Class 1995-2004

Funds Under Management $£$ mn

\begin{tabular}{|c|c|c|c|c|c|c|c|c|c|c|c|}
\hline \multirow[b]{2}{*}{$\begin{array}{l}\text { End } \\
\text { Period }\end{array}$} & \multirow[t]{2}{*}{ Total } & \multicolumn{2}{|l|}{ Equity } & \multicolumn{2}{|l|}{ Bonds } & \multicolumn{2}{|c|}{ Money Market } & \multicolumn{2}{|l|}{ Balanced } & \multicolumn{2}{|l|}{ Other } \\
\hline & & $\begin{array}{l}\text { Funds } \\
\text { Under } \\
\text { MGMT }\end{array}$ & $\begin{array}{l}\% \text { of } \\
\text { Total }\end{array}$ & $\begin{array}{l}\text { Funds } \\
\text { Under } \\
\text { MGMT }\end{array}$ & $\begin{array}{l}\% \text { of } \\
\text { Total }\end{array}$ & $\begin{array}{l}\text { Funds } \\
\text { Under } \\
\text { MGMT }\end{array}$ & $\begin{array}{l}\text { \% of } \\
\text { Total }\end{array}$ & $\begin{array}{l}\text { Funds } \\
\text { Under } \\
\text { MGMT }\end{array}$ & $\begin{array}{l}\% \text { of } \\
\text { Total }\end{array}$ & $\begin{array}{l}\text { Funds } \\
\text { Under } \\
\text { MGMT }\end{array}$ & $\begin{array}{l}\text { \% of } \\
\text { Total }\end{array}$ \\
\hline 2004 Oct & 260,233 & 191,707 & 73.7 & 41,216 & 15.8 & 2,614 & 1 & 19,609 & 7.5 & 5,088 & 2 \\
\hline Nov & 267,902 & 198,654 & 74.2 & 41,406 & 15.5 & 2,607 & 1 & 20,228 & 7.5 & 5,227 & 2 \\
\hline Q 4 Dec & 276,429 & 205,424 & 74.6 & 41,813 & 15.2 & 2,348 & .9 & 20,577 & 7.5 & 5,267 & 1.9 \\
\hline 2006 Jan & 278,434 & 208,073 & 74.7 & 42,579 & 15.3 & 2,266 & .8 & 20,958 & 7.5 & 4,560 & 1.6 \\
\hline Feb & 285,693 & 213,820 & 74.8 & 43,076 & 15.1 & 2,309 &. .8 & 21,788 & 7.6 & 4,701 & 1.6 \\
\hline Q1 Mar & 283,657 & 211,627 & 74.6 & 43,041 & 15.2 & 2,490 & .9 & 21,783 & 7.7 & 4,716 & 1.7 \\
\hline Apr & 277,196 & 204,705 & 73.8 & 43,697 & 15.8 & 2,469 & .9 & 21,563 & 7.8 & 4,761 & 1.7 \\
\hline May & 289,352 & 214,370 & 74.1 & 45,036 & 15.6 & 2,538 & .9 & 22,420 & 7.7 & 4,987 & 1.7 \\
\hline Q2 Jun & 297,725 & 220,493 & 74.1 & 46,305 & 15.6 & 2,567 & .9 & 23,142 & 4.8 & 5,217 & 1.8 \\
\hline Jul & 309,630 & 230,084 & 74.6 & 46,907 & 15.2 & 2,591 & .8 & 23,423 & 7.6 & 5,524 & 1.8 \\
\hline Aug & 312,814 & 233,433 & 74.6 & 47,878 & 15.3 & 2,624 & .8 & 23,210 & 7.4 & 5,669 & 1.8 \\
\hline Q3 Sep & 324,540 & 243,351 & 75 & 48,340 & 14.9 & 2,643 & .8 & 24,309 & 7.5 & 5,899 & 1.8 \\
\hline Oct & 318,045 & 235,260 & 74 & 50,152 & 15.8 & 2,704 & .9 & 23,835 & 7.5 & 6,093 & 1.9 \\
\hline
\end{tabular}

http://www.investmentuk.org/press/2005/stats/stats1005-01.pdf

\section{CONVENIENCE}

As of year-end 2004, there exists, in the United States, over 8,000 mutual funds with over 20,000 share classes accumulating well over $\$ 8$ trillion dollars in assets. ${ }^{12}$ It is no surprise that the U.S. dominates the world market share of mutual funds, holding just over 50\%, as depicted in Figure 5. In comparison, Great Britain had just 2,000 mutual funds with 122 companies comprising 275 £million. This converts at today's exchange rate to be approximately $\$ 481$ billion, considerably less than the U.S. market share of $\$ 8$ trillion. ${ }^{13}$ Considering that Canada had, as of December 2004, just 1,915 funds with approximately \$CDN 260 million, which converts to \$225 billion the total assets under management - are considerably less than the United States as well. ${ }^{14}$ However, both countries have about one-fourth as many funds despite the significant differences in total assets.

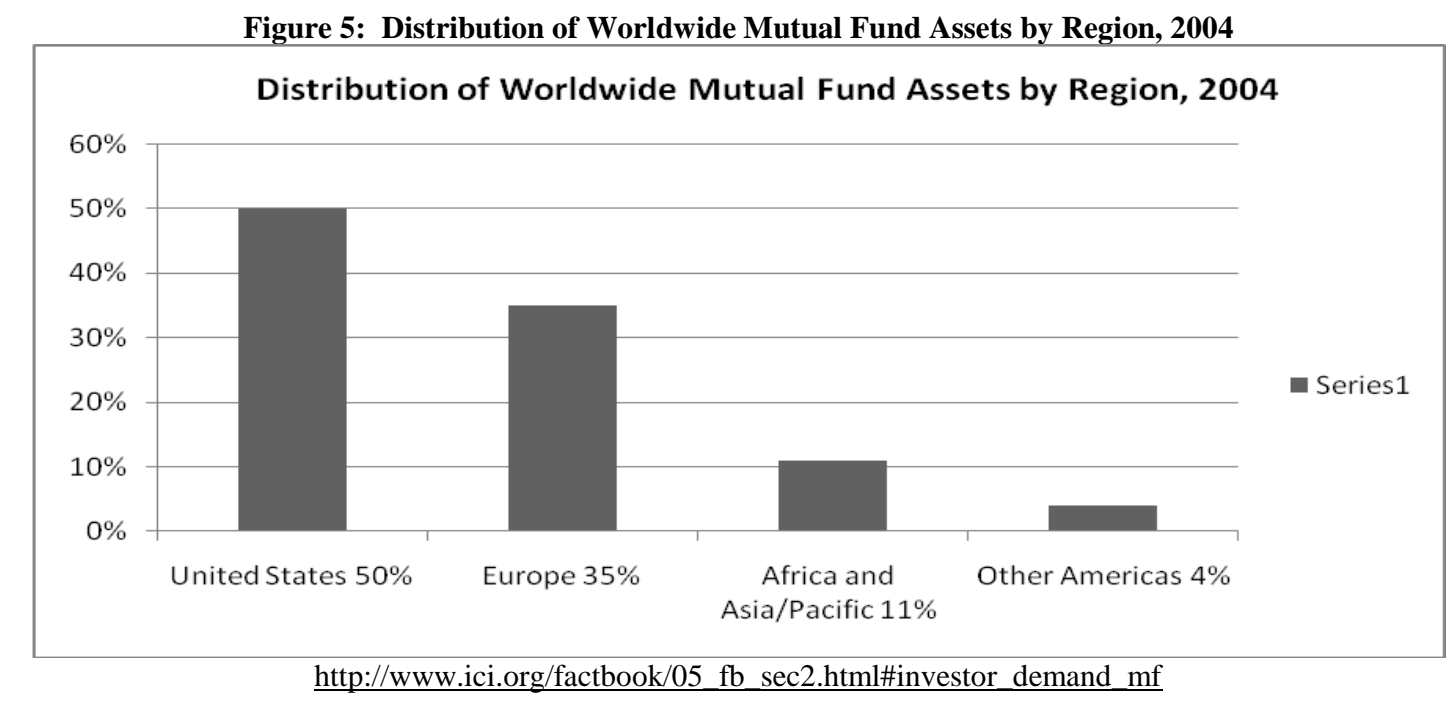

${ }_{12} \frac{\mathrm{http} / / / \text { www.ici.org/factbook/pdf/05_fb_table01.pdf }}{\mathrm{http} / / \text { www.investmentuk.org/press/2004/stats/stats1204-01.pdf }}$
${ }_{14} \underline{\text { https://statistics.ificmembers.ca/English/reports/Canada-US_Review.pdf }}$ 


\section{LIQUIDITY}

As touched upon previously, liquidity stands to be a future driving force behind the management of mutual funds. In the U.S. in 2004, net new cash flow to long-term funds totaled $\$ 475$ billion between January 2003 and February 2005. Investors also reinvested another $\$ 152$ billion in dividends during this period. ${ }^{15}$ Rising interest rates within the U.S. also affected the various funds and investment vehicles in which investors chose to place their money. ${ }^{16}$ This freed up large sums of money, enabling those wishing to exit from funds, to do so relatively easy. As Figure 6 suggests Canadian redemption rates have remained steady over the past five years while U.S. redemption rates have been dwindling since 2002, enabling more liquidity.

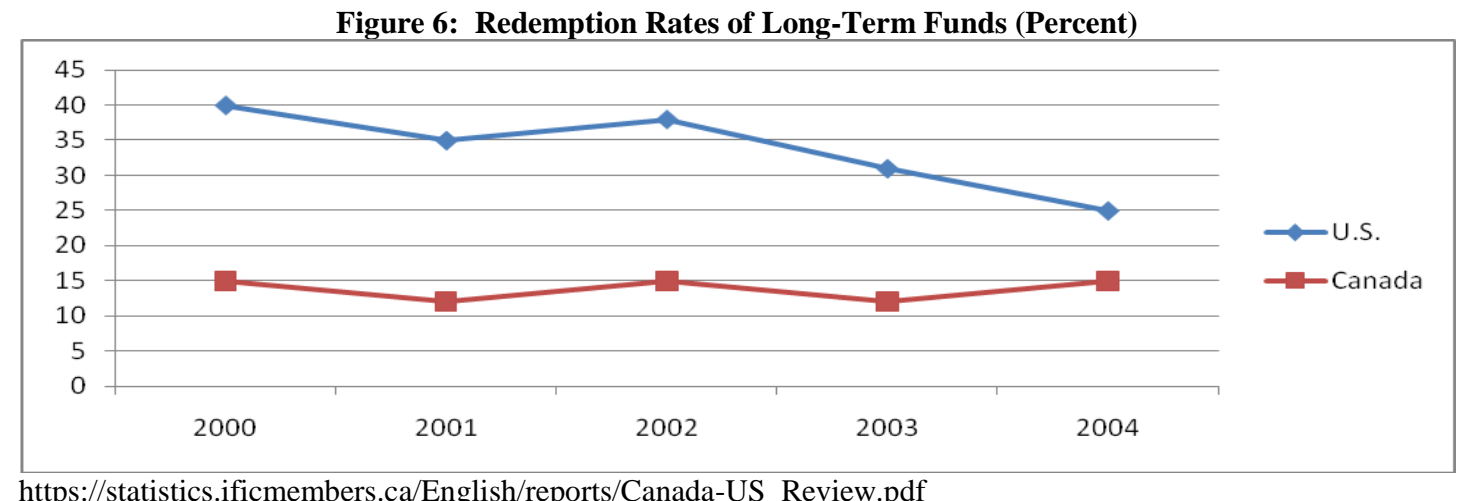

https://statistics.ificmembers.ca/English/reports/Canada-US_Review.pdf

With 56\% of assets in Great Britain held by pension funds and other retirement funds as of May 2004, liquidity is very low, as it is difficult to withdraw money from these funds until retirement. However, the most current survey of the Investment Management Association expects this number to fall and assets in equity funds to increase. ${ }^{17}$ Residents living in the United Kingdom rely heavily on ISAs or Individual Savings Accounts, thereby tying up their money for future use, such as education and retirement. Similarly, 59\% of U.S. investors own mutual funds through defined benefit and defined contribution retirement plans. These tax-deferred vehicles have risen in importance, along with IRAs, over the past 25 years as the large Baby Boomer segment of the U.S. population began preparing for retirement. ${ }^{18}$ Canada has only $\$ 580$ million tied up in pension assets, which is much lower than the numbers for the U.S. and the United Kingdom. ${ }^{19}$

The mutual fund industry in Canada in 2001 was composed of 55\% in equity accounts, $15 \%$ in the money market account, $8 \%$ in the bond/income account, and the remaining $22 \%$ was invested in balanced, dividend/income accounts, and mortgages/real estate accounts. See figure 7. It seems obvious why equity accounts in Canada are so large when compared to the other accounts within their country. Investors know that when they purchase these securities, they probably will have higher risk; however, it is known that over long periods of time, common stocks should outperform money market and bond accounts. ${ }^{20}$

Clone funds, or as they are commonly known in the United States as index funds, became increasingly popular from 2001-2005 until a legislative law changed all that. In mid-2005, the Canadian legislature changed the limits on the amount of foreign investment that investors could have in their Registered Retirement Savings Plan (RRSP). If an investor wanted to avoid this, for example, they would invest in a clone fund (index fund) because it is considered a Canadian security since the fund invests in Canadian companies. ${ }^{21}$

\footnotetext{
${ }^{15} \mathrm{http} / / /$ www.ici.org/factbook/05_fb_sec2.html\#investor_demand_mf

$16 \mathrm{http} / / /$ www.ici.org/factbook/05 fb sec2.html\#investor demand $\mathrm{mf}$

17 http://www.investmentuk.org/press/2004/20040526.asp

18 http://www.ici.org/factbook/05 fb sec4.html

${ }_{19}$ Benefits Canada, Nov2004, Vol. 28 Issue 11, p28, 7p

${ }^{20}$ Department of Finance. "Canada's Mutual Fund Industry." Canada. March 2002. 11/30/2005. http://www.fin.gc.ca/toce/2002/cmfi e.html

${ }^{21}$ http://www.investopedia.com/terms/c/clonefund.asp
} 
Figure 7: Mutual Fund Structure - Canada

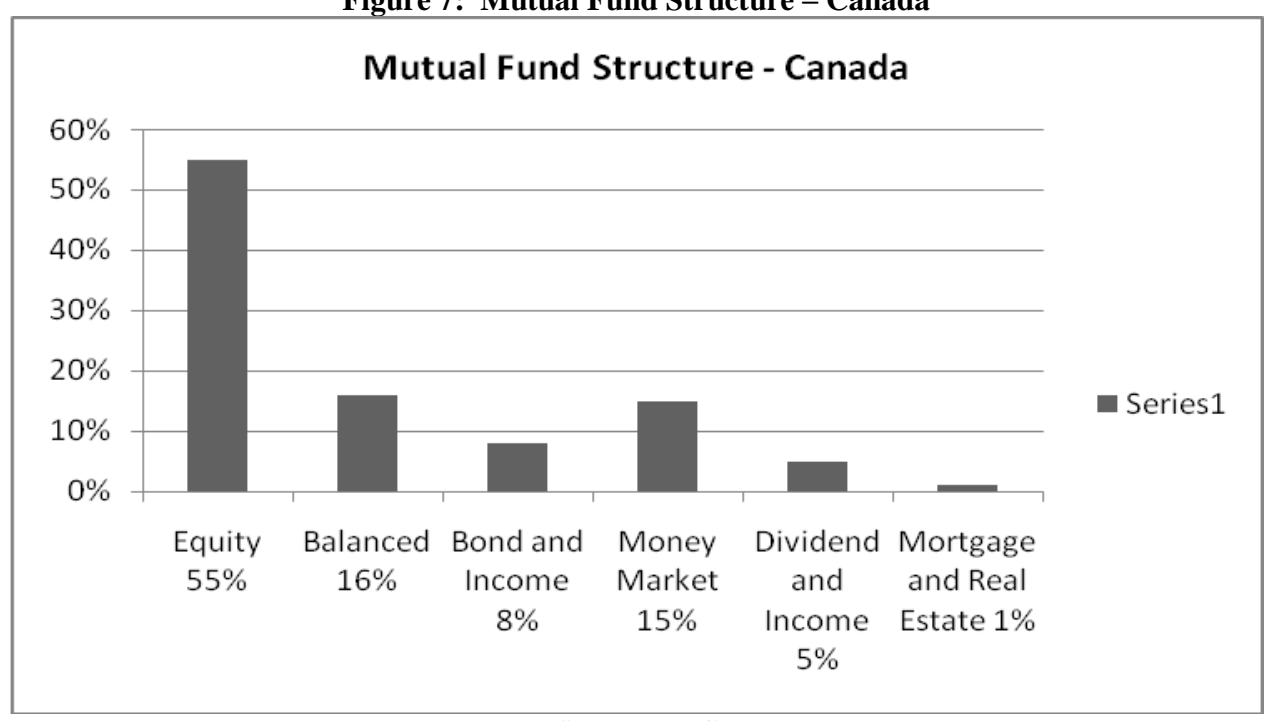

Source: IFIC

In comparison, the United Kingdom in 2003 was comprised of $63.8 \%$ in equity funds, $14.1 \%$ in bond funds, $11.9 \%$ in unsegmented offshore funds, $3.5 \%$ in money market funds, $2.9 \%$ in balanced funds, and the remaining $3.7 \%$ is property and other funds. ${ }^{22}$ See Figure 8.

Although the United Kingdom's compounded annual growth rate (CAGR) in 2003 was $20.50 \%$, it was dramatically lower from the 1999-2003 period. The CAGR for this period was $-1.7 \%$. The reason for this was economic instability in 2001 and 2002. In 2001 the CAGR was $(-9.50 \%)$ and in 2002 it was $(-17.80 \%) .{ }^{23}$ During this two-year period, the United Kingdom was experiencing an economy that was beginning to slow down prior to the 9-11 attacks that occurred in the United States. There was also a weak external demand, and business investment was low in the country as the UK was experiencing surging oil prices.

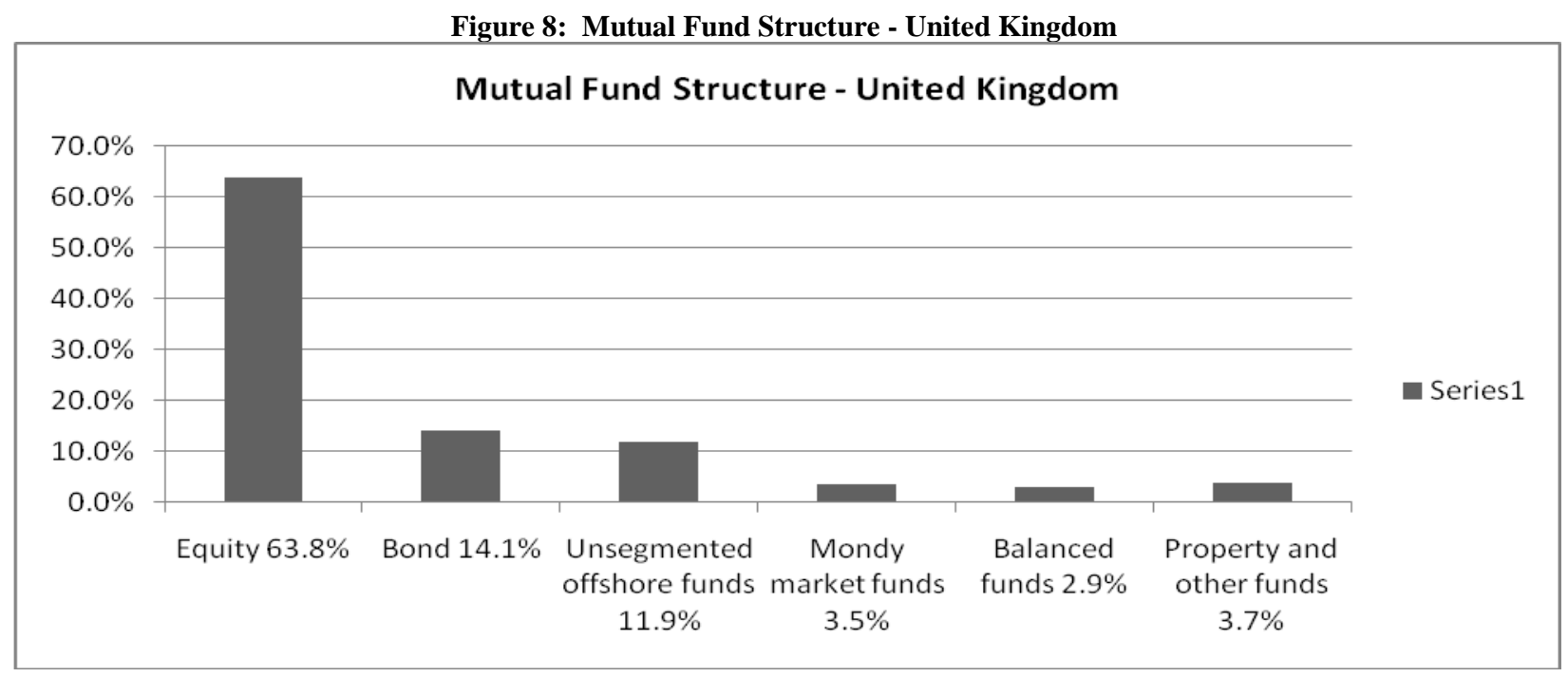

\footnotetext{
${ }^{22}$ DataMonitor. "Mutual Funds in the United Kingdom.” November 2004. 11/29/2005.

${ }^{23}$ Investment Company Institute. "How is the Fund Industry Structured?” ICI. January 2004. 11/26/2005. http://www.ici.org/pdf/04fb_ch3.pdf
} 
Their economy was in a normal fluctuation pattern, as was the case in the United States prior to the terror attacks of 9-11. All of these factors ultimately lead to 2001 and 2002 producing poor market values for unit trusts or, as they are known in the United States, mutual funds.

In the United States, the structure of the mutual fund industry as of 2003 was $56.6 \%$ in equity funds, $31.4 \%$ in bond and hybrid funds, and $12 \%$ in money market funds. See figure 9. By comparison, at the end of 1970, 95\% of mutual funds was invested in equity funds. The remaining $5 \%$ was invested in bonds. ${ }^{24}$

The year 1971 marked the introduction of the first money market funds in the United States. This avenue for investing in mutual funds was extremely popular because it enabled investors to invest in short-term assets at a time when the United States' economy was experiencing rising interest rates; this also was when prices began to decline in equity funds. Nine years after the introduction of money market funds, the structure dramatically changed. In 1980, 56.7\% of mutual funds was invested in money market funds while $32.9 \%$ were in equity funds and $10.4 \%$ were composed of bond and income funds. The nine-year period did not show how popular money market funds were; rather, it showed how important economic factors were in determining the mutual fund structure within the United States. ${ }^{25}$

Figure 9: Mutual Fund Structure - United States

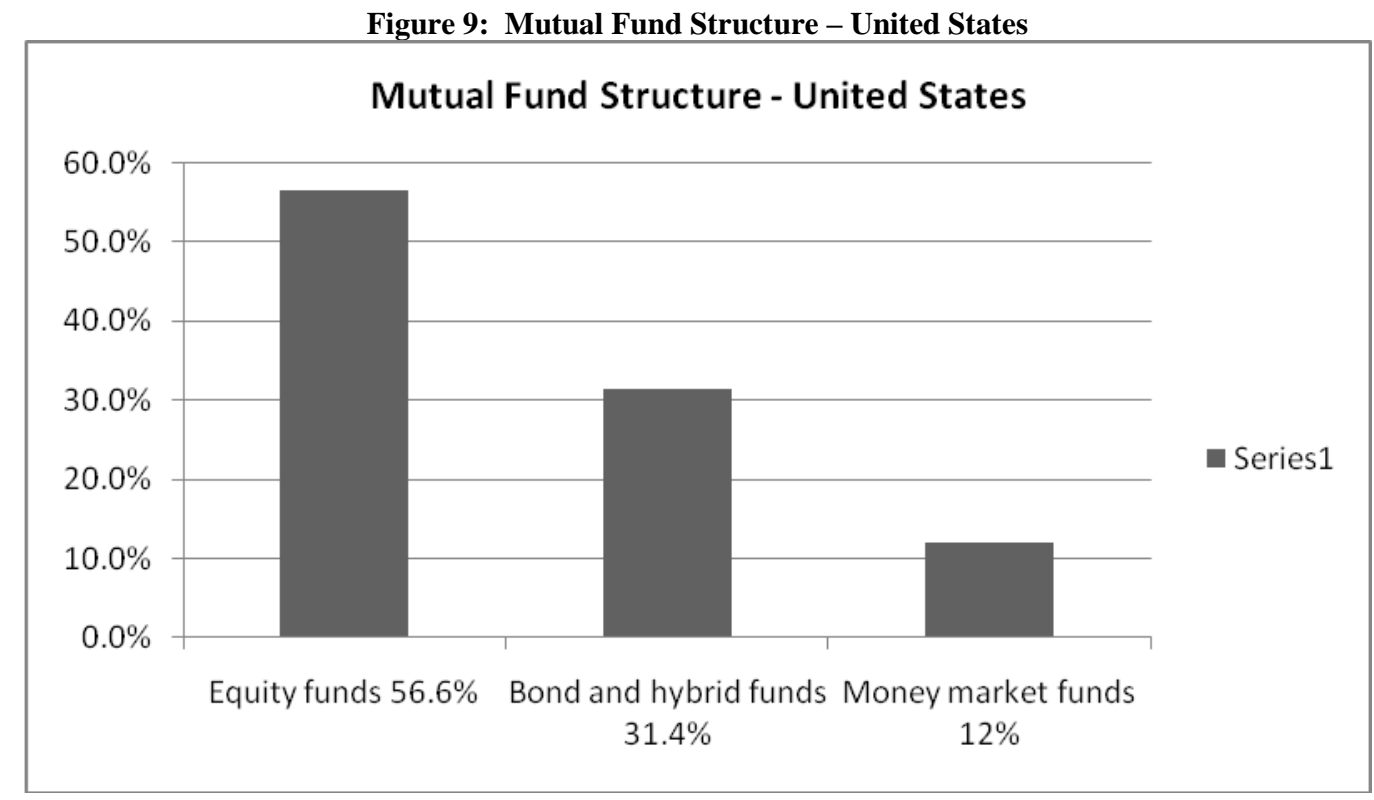

We can infer that from the three countries of Canada, the United Kingdom, and the United States all possess very comparable mutual fund structures. All three of these countries have the majority of their mutual funds invested in equity funds. The United Kingdom has the highest at nearly $64 \%$ and the United States and Canada invest $57 \%$ and $55 \%$, respectively, in equity funds.

In addition to the similarity in equity funds, there is a close comparison in money market funds within these countries. The percent invested in money market funds tends to be one of the lowest forms of any investment. This may have to do with similar economic conditions because if the economy is prosperous in these countries, money market funds will offer investors a low incentive to invest as compared to investment in equity funds.

Unlike the similarities of mutual fund structure between the three countries, the size of the mutual funds assets are comprised of dramatically different assets. The United States, as of 2003, had \$7.414 trillion in mutual

\footnotetext{
${ }^{24}$ Investment Company Institute. "How is the Fund Industry Structured?"

${ }^{25}$ Investment Company Institute. "How is the Fund Industry Structured?"
} 
fund assets. $^{26}$ The United Kingdom and Canada have dramatically lower numbers when compared to the United States. As of 2003, the United Kingdom had mutual fund assets valued at only a fraction of the United States' assets, $\$ 551.4$ billion. $^{27}$ In Canada, the numbers are even smaller. As of 2001, Canada's mutual fund assets were valued at $\$ 426$ billion. Total market share of the mutual fund industry in Canada is estimated at approximately $5-7 \%{ }^{28}$

In addition to the size of the mutual funds in these countries being varied, there is another major difference - fees. In particular, expense ratios, which comprise the management and distribution fees, as well as other expenses associated with administering a mutual fund. According to The United Kingdom Times, the average United Kingdom fund has an expense ratio of 1.63. In comparison, the United States has an expense ratio of only $1.4 \% .^{29} \mathrm{When}$ compared to the United Kingdom and the United States, Canada has the highest expense ratio at $2.1 \%{ }^{30}$ The discrepancy in costs has to do with citizens of Canada and the United Kingdom investing proportionately more in global equity funds, which generally have higher expense ratios.

These expense percentages may not seem like a drastic difference, in part, because the range is only $0.7 \%$; however, over long periods of time, it can dramatically affect the value of your investment. See Figure 10. For example, suppose you invested $\$ 10,000$ in mutual funds in all three nations for ten years, and hypothetically, you would receive the same return of $10 \%$ in all of the countries. After the tenth year, your values for all three mutual funds would be greatly differentiated. Your expense ratio range may have only been $0.7 \%$, but your total value range after year ten is nearly $\$ 1,600$.

Figure 10: Effects of High Expense Ratios

\begin{tabular}{|c|c|c|c|}
\hline & Canada & United Kingdom & United States \\
\hline Initial Investment & $\$ 10,000$ & $\$ 10,000$ & $\$ 10,000$ \\
\hline Annual Expense Ratio & 2.1 & 1.63 & 1.4 \\
\hline Assume Average Return of $10 \%$ for 10 Years & $10 \%$ & $10 \%$ & $10 \%$ \\
\hline Year one value & $\$ 10,769.00$ & $\$ 10,820.70$ & $\$ 10,846.00$ \\
\hline Year two value & $11,597.14$ & $11,708.75$ & $11,763.42$ \\
\hline Year three value & $12,488.96$ & $12,669.69$ & $12,758.60$ \\
\hline Year four value & $13,449.36$ & $13,709.49$ & $13,867.98$ \\
\hline Year five value & $14,483.61$ & $14,834.63$ & $15,041.21$ \\
\hline Year six value & $15,597.40$ & $16,052.11$ & $16,313.69$ \\
\hline Year seven value & $16,796.84$ & $17,369.51$ & $17,693.83$ \\
\hline Year eight value & $18,088.52$ & $18,791.73$ & $19,190.73$ \\
\hline Year nine value & $19,479.53$ & $20,333.96$ & $20,814.27$ \\
\hline Year 10 value & $20,977.51$ & $22,002.77$ & $22,575.16$ \\
\hline
\end{tabular}

Individuals who are seriously dedicated to performing well in the mutual fund industry must be aware of the similarities and differences in various countries' funds. These similarities and differences would include the structure of the mutual funds in various countries, the size of the market in terms of assets and, most importantly, fees that are associated with managing the mutual funds (i.e., expense ratios). Who would have ever thought that the first mutual fund concept that originated in Holland would eventually be so prosperous? Selecting the right mutual fund in the right country can be very demanding and time consuming, but the rewards can be very satisfying to those investors who are patient enough to do the required research and analysis.

\footnotetext{
${ }^{26}$ DataMonitor. "Mutual Funds in the United Kingdom."

${ }^{27}$ Department of Finance. "Canada’s Mutual Fund Industry.” Canada. March 2002. 11/30/2005. http://www.fin.gc.ca/toce/2002/cmfi e.html

${ }^{28}$ Department of Finance. "Canada's Mutual Fund Industry."

${ }^{29}$ Atherton, Mark. "Americans Pay Less for Their Funds." United Kingdom Time, 10/29/2005.

${ }^{30}$ Kivenko, Ken. "Mutual Funds: Canada and the United States." FundAlarm. 12/7/2005. http://www.fundalarm.com/arc0102b.htm.
} 


\section{PROFESSIONAL MANAGEMENT}

It becomes difficult to gauge the real returns of professional fund managers as they often do not risk adjust or market adjust their returns. For the purposes of this analysis, we will assume the returns of managers are comparable for all countries. Most important, in regard to professional management, is the ethical nature and regulation placed upon them to disclose information to investors. This is where we find the most differences within the mutual fund industry. In the U.S., "a mutual fund is required to send a prospectus to its investors and anyone who requests it. A prospectus is a legal document that details the fund's investment objectives and policies. It also outlines the risks, expenses and fees associated with investing in the fund. It is important that people read a fund's prospectus very carefully before investing money in a mutual fund." ${ }^{31}$ This form of disclosure helps to get investors acquainted to related fees and expectations for their fund. However, there seem to be many scandals involving market timing within the U.S fund industry, unlike the industries located in Canada and the United Kingdom. This could be the result of Canada's generally accepted principle to disclose market timing policies along with valuation practices. In Canada, "there appear to be no grounds for complaints about the integrity of the industry, which is scandal-free." 32 The second example of abuses within the U.S., which comprises much of the $\$ 2$ billion or more in fines, involves what is known as "late trading." "This involves various schemes in which fund firms allow a handful of large investors to make trades after markets have closed," allowing those investors to act on information that most investors cannot access. This, of course, is both illegal and unethical. ${ }^{33}$ The United Kingdom has created mutual fund classes for those investors concerned about investing in ethical funds. These funds are concerned with keeping investors informed about the issues mentioned above, as well as recommending holding companies that do not involve themselves with unethical activities. ${ }^{34}$

\section{COSTS}

Fund expense ratios differ among investments made in the U.S., Canada and the United Kingdom. Funds within the U.S. are subject to $12 \mathrm{~b}-1$ fees, as outlined by the SEC. This $12 \mathrm{~b}-1$ fee - or distribution fee - is "collected to compensate financial advisers and other financial intermediaries for assisting fund investors before and after they purchase fund shares, while using only a small fraction of the 12b-1 fees that they collect for advertising and promotion." ${ }^{35}$ This fee, along with the management fee and other expenses, are taken out of the funds' assets before distributions are made. U.S funds might also be subject to sales charges, often called loads, redemption fees, as well as exchange fees and annual account maintenance fees. These fees are paid directly by an investor. ${ }^{36}$ In the United Kingdom, mutual funds are also subject to annual management fees and this tends to be 1 to $1.5 \%$ of the investment value. Funds also charge trustee and audit fees, which might be comparable to U.S.A. $12 \mathrm{~b}-1$ fees. ${ }^{37}$ However, there remains much more latitude as far as how management or performance fees are calculated. Performance fees in the United Kingdom may be implemented based on fee scales, net assets, sliding performance (meaning the fee decreases if the manager does not meet their benchmark) and other such options. ${ }^{38}$ In comparison, expenses or fees in the U.S. are based upon type of fund, size of fund, and the average amount in the fund's shareholder accounts. ${ }^{39}$ As Figure 11 demonstrates, the operating expense ratio for U.S. funds has gradually decreased while the ratio paid by shareholders has increased slightly since 1998. In contrast to funds within the U.S. and the United Kingdom, annual management fees on Canadian mutual funds range from 2 to $3 \%$. As a result, many Canadian investors seem to be moving toward exchange-traded funds in order to save on fees. ${ }^{40}$ Their threshold of 15 makes it more difficult to make the returns to cover operating expenses and desired profits. ${ }^{41}$ Until recently, Canadian investors had a $30 \%$

\footnotetext{
${ }^{31} \mathrm{http} / / /$ www.younginvestor.com/teens/investIt/articleWhatsaMutualFund.asp

32 Kelman, Steven. “The Canadian Way.” CAMagazinge, November 2004.

${ }^{33}$ Maclean's, 10/4/2004, Vol. 117 Issue 40, p39, 1p

${ }_{35}^{34}$ http://www.investmentuk.org/fact_sheets/E/EthicaLFactsheet.pdf

$35 \mathrm{http://www.ici.org/factbook/05} \mathrm{fb} \mathrm{sec} 3 . \mathrm{html}$ \#mutual fund service

${ }_{36} \mathrm{http} / / /$ www.ici.org/factbook/05_fb_appb.html

${ }_{37} \mathrm{http}: / /$ www.investmentuk.org/fact sheets/II/introducinginvestment.pdf

${ }_{38} \mathrm{http} / / /$ www.investmentuk.org/news/standards/pfees-techpaper.pdf

39 http://www.ici.org/factbook/05_fb_sec3.html\#mutual_fund_service

40 Canadian Business; 10/25/2004, Vol. 77 Issue 21, p162-163, 2p, 1

${ }_{41}$ Global Investor; Mar2005 Issue 180, p50-52, 2p, 1 chart, 1c, 2bw
} 
limit on foreign investments in retirement accounts and pension funds. ${ }^{42}$ This, too, should help to diminish the cost of owning a fund.

Figure 11: Stock Fund Operating Expense Ratios, 1990-2003 (Percent)

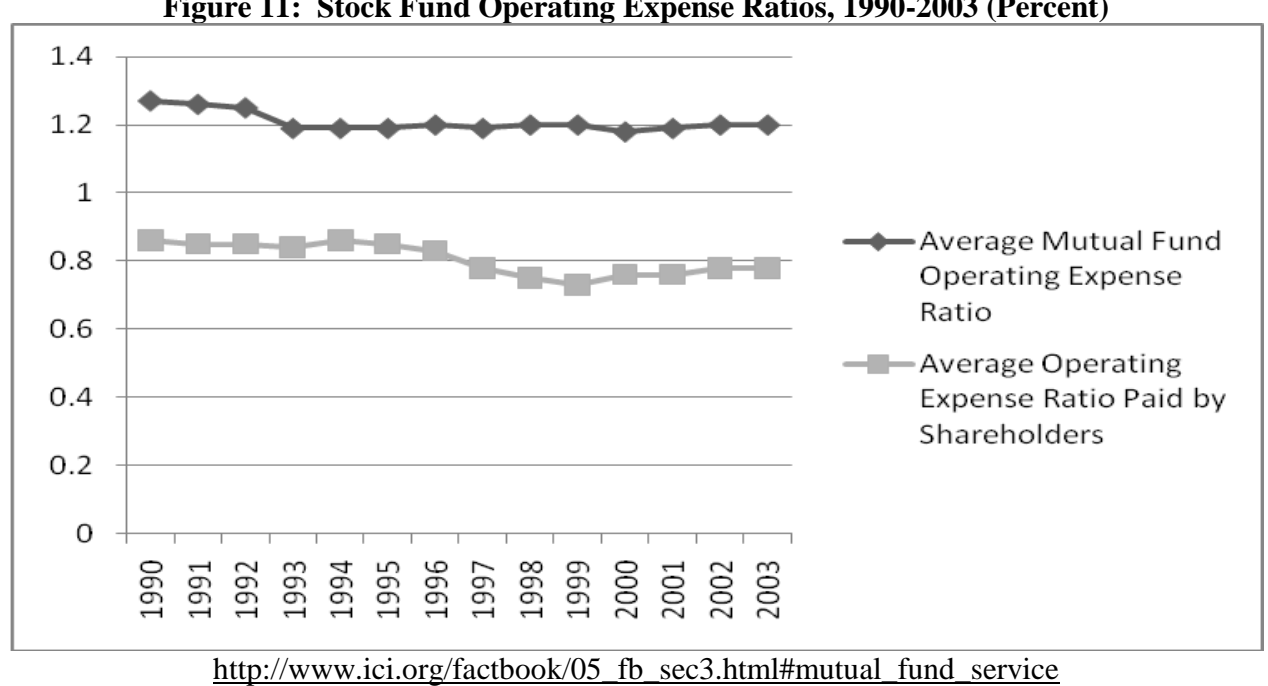

http://www.ici.org/factbook/05_fb_sec3.html\#mutual_fund_service

\section{TAXATION}

U.S. Mutual funds are forced by law to distribute at least $90 \%$ of the total realized capital gains and dividend income each year. Late December is the most popular time for a fund company to pay out distributions. ${ }^{43}$ With this being the case, investors might be prone to avoid buying U.S. funds before distribution time in order to prevent having to claim ordinary income. Currently, capital gains are taxed at a rate of $15 \%$, although some investors may receive a lower rate. This means that if an investor is to take a distribution outside of a tax-deferred account, as mentioned below, they will be subject to this dividend or capital gains tax. U.S. investors also have the option of acquiring funds within tax-deferred accounts, such as 401(k) plans, IRAs, and 403(b) accounts. Tax is not incurred as a result of dividend and capital gain distributions, or from the sale of fund shares, until the investor withdraws distributions from their tax-deferred account. ${ }^{44}$ Canadian investors also have the ability to invest mutual funds tax-deferred in retirement accounts, such as Registered Education Savings Plans (RESP). In fact, the government will contribute up to $\$ 400$ per year per child, based on $20 \%$ of your contribution (on the first $\$ 2,000$ per year). However, there are certain restrictions on how the money can be used. ${ }^{45}$ Furthermore, in the February 2000 budget, the Federal government reduced the capital gains inclusion rate from three-quarters to two-thirds and then once again from two-thirds to one-half. ${ }^{46}$ This is the portion of a capital gain that is subject to income tax. ${ }^{47}$ As a result, capital gains are now taxed more favorably than dividends for a taxpayer in the top tax bracket. ${ }^{48}$ For investors within the United Kingdom, your tax position will depend on the type of distribution you receive, whether it is an interest distribution or a dividend distribution. Investors within the United Kingdom do not have to pay tax on distributions in ISAs or Individual Savings Accounts until they begin to withdraw from those accounts. Outside of an ISA, investors should receive a tax voucher from the fund manager showing the amount you are due to receive and the amount of any tax on the distribution that has been paid by the manager. This voucher is then transferred onto a tax return and matched up with the applicable tax credit to determine the tax liability. ${ }^{49}$ Especially important

\footnotetext{
${ }^{42}$ Maclean's; 3/7/2005, Vol. 118 Issue 10, p33-33, 1/3p

${ }^{43} \mathrm{http}: / /$ mutualfunds.about.com/cs/taxes/a/distributions.htm

44 http://www.ici.org/factbook/05_fb_appa.html

$45 \mathrm{http://cfpg.sentex.ca/articles/article} \mathrm{details.asp?ArticleID=435 \& Switch}$

46 http://www.ific.ca/eng/frames.asp?11=Statistics

${ }^{47} \mathrm{http} / / /$ www.fin.gc.ca/toce/2002/cgtc_e.html

48 http://www.grantthornton.ca/mgt papers/MIP Capital Gains.pdf\#search='capital\%20gains\%20inclusion \%20rate'

49 http://www.investmentuk.org/fact_sheets/tax/taxfactsheet.pdf
} 
for investors within the United Kingdom is the way in which capital gains are taxed. "Capital gains and losses on assets are not included in the computation of net income, except when the taxpayer makes transactions in such assets affecting his trade or business." Thus, non-recurring, or occasional profits arising from transactions that do not form part of the ordinary business of the person who makes them are non-taxable, such as short-term gains from the sale of a mutual fund.$^{50}$ It is important to note that dividend distributions are also taxable. This is a significant difference between taxation in Canada and the U.S. and might prove helpful in deciding whether or not to purchase an investment before a distribution or sell it after a shorter period of time.

\section{CONCLUSION}

As an investor, it is easy to see that the similarities and differences between the mutual fund industries in the United States, Canada and the United Kingdom are significant enough to merit valuable consideration when determining whether or not to invest in mutual funds domestically or internationally. Major similarities exist in the variety of mutual funds, uses of the funds, and professional management. However, there exist major differences in the number of funds available, costs and fees involved, the ethical responsibility of managers to investors, and the tax implications for the distributions of funds. Assuming identical returns for various fund managers, the authors illustrated that funds will grow the fastest in the United States, followed by the United Kingdom, and lastly, Canada, which would yield the smallest nest egg. The expense ratios were $1.4 \%$ for the United States, $1.63 \%$ for the United Kingdom, and $2.1 \%$ for Canada. As always, an investor should carefully weigh his/her financial needs when choosing a mutual fund, while keeping in mind the advantages and disadvantages of mutual funds in the United States, Canada and the United Kingdom.

\section{AUTHOR INFORMATION}

Brian D. Fitzpatrick is a professor of finance for the Helzberg School of Management at Rockhurst University in Kansas City, Missouri. He earned his Ph.D. in Finance with a concentration in Investments from Saint Louis University. Dr. Fitzpatrick spent ten years in the Investment field including positions with two major Wall Street wire houses, as well as serving as senior vice president for both Financial Corporation of America and Commerce Bancshares. Brian has won the Rockhurst University's Teaching Excellence Award, and he has published in nine different fields.

Daniel C. Hepp was born and raised in Southern Illinois. He attended Rockhurst University in Kansas City, MO where he graduated in 2006 with a Bachelors' of Science in Business Administration emphasis in Finance/Economics. After receiving his undergraduate diploma, Dan enrolled at McKendree University where he received his Master of Business Administration in 2008. Dan began his career working for a broker dealer and now is currently working for a Managed Account Provider in St. Louis, MO in the sales and marketing department. When he is not working, Dan enjoys training for marathons and spending time with family and friends.

Erinn J. Lott earned a BS/BA degree with a concentration in accounting and finance from Rockhurst University in May, 2006. This work commenced by participating in the Gould Undergraduate Research Project dealing with studying mutual funds. Erinn has moved to the New York area, where he works in the finance area.

\section{REFERENCES}

1. "A Guide to Ethically and Socially Responsible Investment Funds.” IMA. Online December 11, 2005. http://www.investmentuk.org/fact_sheets/E/EthicaLFactsheet.pdf

2. $\quad$ About. "The History of Mutual Funds." About.com. 12/1/2005. http://mutualfunds.about.com/cs/history/a/fund history.htm

3. "Advantages of Mutual Funds." Yahoo Finance. Online December 11, 2005. http://finance.yahoo.com/funds/basics/article/100623/Advantages_of_Mutual_Funds

4. "Advantages and Disadvantages of Mutual Funds." Abacus Consulting Services. Online December 11, 2005- http://chinese-school.netfirms.com/abacus-mutual-funds-advantages.html

${ }^{50}$ http://www.taxanalysts.com/thp/civilization/Documents/Surveys/hst23731/23731-1.htm 
5. $\quad$ Atherton, Mark. "Americans Pay Less for Their Funds." United Kingdom Time, The 10/29/2005.12/7/2005.http://web2.epnet.com/citation.asp?tb=1\& us=sid+F3892D4F\%2D196B\%2D4603\% 2DA538\%2DB93400CE92C0\%40sessionmgr4+dbs+aph\%2Cf5h\%2Cnfh\%2Cbuh\%2Cc8h\%2Culh $\% 2 \mathrm{Cprh}$ $\% 2 \mathrm{Cafh}+\mathrm{cp}+1+\mathrm{D} 668 \&$ \&us=hd+False+hs+False+or+Date+fh+False+ss+SO+sm+ES+sl+\%2D1+ri+KAAA CBWA00011671+dstb+ES+mh+1+frn+1+EA15\&_uso=\%5f2\&cf=1\&fn=1\&rn=1.

6. $\quad$ "Canada/US Review." IFIC. Online December 11, 2005. https://statistics.ificmembers.ca/English/reports/Canada-US_Review.pdf

7. "Capital Gains." Grant Thornton. Online December 11, 2005. http://www.grantthornton.ca/mgt_papers/MIP_Capital Gains.pdf\#search='capital\%20gains\%20inclusion \%20rate'

8. "Capital Gains Tax Cut.” Department of Finance Canada. Online December 11, 2005. http://www.fin.gc.ca/toce/2002/cgtc_e.html

9. The Columbia Electronic Encyclopedia, Sixth Edition Copyright @ 9 2003, Columbia University Press.

10. "Completing Your Tax Return." IMA. Online December 11, 2005http://www.investmentuk.org/fact sheets/tax/taxfactsheet.pdf

11. DataMonitor. "Mutual Funds in the United Kingdom." November 2004. 11/29/2005. http://web2.epnet.com/externalframe.asp?tb=1\& us=sid+F3892D4F\%2D196B\%2D4603\%2DA538\%2DB 93400CE92C0\%40sessionmgr4+dbs+aph\%2Cf5h\%2Cnfh $\% 2 \mathrm{Cbuh} \% 2 \mathrm{Cbwh} \% 2 \mathrm{Cc} 8 \mathrm{~h} \% 2 \mathrm{Culh} \% 2 \mathrm{Cprh} \% 2 \mathrm{Ca}$ fh+cp+1+D668\& us=hd+False+hs+False+or+Date+fh+False+ss+SO+sm+ES+sl+\%2D1+ri+KAAACBW A00011479+dstb+ES+mh+1+frn+1+1C1D\& uso=\%5F1\&fi=buh 16893258 AN\&lpdf=true\&pdfs=136K $\& \mathrm{bk}=\mathrm{R} \& \mathrm{tn}=4 \& \mathrm{tp}=\mathrm{CP} \& \mathrm{es}=\mathrm{cs} \% 5 \mathrm{Fclient} \% 2 \mathrm{Easp} \% 3 \mathrm{FT} \% 3 \mathrm{DP} \% 26 \mathrm{P} \% 3 \mathrm{DAN} \% 26 \mathrm{~K} \% 3 \mathrm{D} 16893258 \% 26 \mathrm{rn} \% 3$ D1\%26db\%3Dbuh\%26is\%3D\%26sc\%3DR\%26S\%3DR\%26D\%3Dbuh\%26title\%3DMutual\%2BFunds\%2 BIndustry\%2BProfile\%253A\%2BUnited\%2BKingdom\%26year\%3D2004\%26bk\%3D\&fn=1\&rn=1

12. $\quad$ Department of Finance. "Canada’s Mutual Fund Industry." Canada. March 2002. 11/30/2005. http://www.fin.gc.ca/toce/2002/cmfi_e.html

13. "Funds and Taxation." ICI. Online December 11, 2005- http://www.ici.org/factbook/05_fb_appa.html

14. Haas, George. "Tax Revision Studies: Tax Treatment of Capital Gains and Losses." Online December 11, 2005 http://www.taxanalysts.com/thp/civilization /Documents/Surveys/hst23731/23731-1.htm

15. "How Funds Operate.” ICI. Online December 11, 2005- http://www.ici.org/factbook/05 fb_appb.html

16. "Industry Statistics." IFIC. Online December 11, 2005- http://www.ific.ca/eng/frames.asp?11=Statistics

17. Introducing Investment." IMA. Online December 11, 2005. http://www.investmentuk.org/fact sheets/II/introducinginvestment.pdf

18. Investment Company Institute. "How is the Fund Industry Structured?" ICI. January 2004. 11/26/2005. http://www.ici.org/pdf/04fb_ch3.pdf

19. Investopedia. "Clone Fund." Investopedia.com. 12/3/2005. http://www.investopedia.com/terms/c/clonefund.asp

20. $\quad$ Kelman, Steven. "The Canadian Way.” CAMagazinge, November 2004.

21. Kivenko, Ken. "Mutual Funds: Canada and the United States." FundAlarm. 12/7/2005. http://www.fundalarm.com/arc0102b.htm

22. $\quad$ MacDonald, Jim. “Top Forty.” Benefits Canada, Nov2004, Vol. 28 Issue 11, p28, 7p.

23. Macklem, Katherine. “A Surprise RRSP Gift.” Maclean's; 3/7/2005, Vol. 118 Issue 10, p33-33, 1/3p.

24. Mahmud, Shahnaz. "Different Strokes for Canadian Folks." Global Investor; Mar2005 Issue 180, p50-52, $2 \mathrm{p}, 1$ chart, $1 \mathrm{c}, 2 \mathrm{bw}$.

25. Maich, Steve, "The scandal that isn't.” Maclean's, 10/4/2004, Vol. 117 Issue 40, p39, 1p.

26. "Mutual Fund Fees and Expenses." Investment Company Institute. Online December 11, 2005. http://www.ici.org/factbook/05 fb_sec3.html\#mutual_fund_service

27. "The Mutual Fund Guide." CFP Group. Online December 11, 2005. http://cfpg.sentex.ca/articles/article details.asp?ArticleID=435\&Switch

28. $\quad$ "Performance Fees for Investment Funds." IMA. Online December 11, 2005. http://www.investmentuk.org/news/standards/pfees-techpaper.pdf

29. "Press Release." IMA. Online December 11, 2005. http://www.investmentuk.org/press/2004/20040526.asp

30. "Recent Mutual Fund Trends." Investment Company Institute. Online December 11, 2005. http://www.ici.org/factbook/05_fb_sec2.html\#individual_investors 
31. "Recent Mutual Fund Trends." Investment Company Institute. Online December 11, 2005. http://www.ici.org/factbook/05 fb_sec2.html\#investor_demand_mf

32. Sanford, Jeff. "Let the free revolt begin." Canadian Business; 10/25/2004, Vol. 77 Issue 21, p162-163, 2p, 1.

33. “Summary.” IMA. Online December 11, 2005- http://www.investmentuk.org/press/2004/stats/stats120401.pdf

34. "Understanding Mutual Fund Distributions." About.com. Online December 11, 2005. http://mutualfunds.about.com/cs/taxes/a/distributions.htm

35. "U.S. Mutual Fund Totals.” Investment Company Institute. Online December 11, 2005. http://www.ici.org/factbook/pdf/05 fb table01.pdf

36. Viking. "The Origins of Mutual Funds." Yale. 11/25/2005. http://viking.som.yale.edu/geert/origins.html

37. Wells Fargo. "Types of Mutual Funds.” Wells Fargo. 11/30/2005.

http://mutualfunds.about.com/cs/history/a/fund history.htm

38. "What's a Mutual Fund." Young Investor. Online December 11, 2005. http://www.younginvestor.com/teens/investIt/articleWhatsaMutualFund.asp

39. "Who Owns Mutual Funds." Investment Company Institute, Online December 11, 2005. http://www.ici.org/factbook/05_fb_sec4.html. 